\title{
TINDAK TUTUR DAN FUNGSI KATA BI DAN BA DALAM PROSES KOMUNIKASI BAHASA DAYAK Studi Kasus pada Masyarakat Riam Durian
}

\author{
Sri Hartuti \\ Ika Nurfarida \\ veritas109127@gmail.com \\ kaa.farida@gmail.com
}

Universitas Airlangga

\begin{abstract}
Abstrak
Masing-masing kata dalam bahasa daerah memiliki fungsi yang berbeda dengan daerah lainnya. Oleh sebab itu, pemahaman tentang fungsi kata sangat penting. Fungsi kata hanya bisa dipahami jika konteks kalimat jelas, apakah kalimat termasuk termasuk kalimat imperatif, deklaratif, atau interogatif. Salah satu fenomena yang berkaitan dengan fungsi kata yakni kata bi dan ba dalam bahasa Dayak di desa Riam Durian, kecamatan Kotawaringin Lama, Kabupaten Kotawaringin Barat, Kalimantan Tengah. Berdasarkan data yang dianalisis, kata bi hanya digunakan apabila seseorang ingin membuat kalimat interogatif atau kalimat tanya, sedangkan kata ba hanya digunakan apabila seseorang ingin membuat kalimat imperatif atau kalimat perintah. Selain itu, kata bi jika dikaitkan dengan teori tindak tutur ternyata memenuhi unsur sebagai bagian dari tindak tutur direktif, sedangkan kata ba memenuhi unsur sebagai bagian dari tindak tutur komisif. Meskipun demikian, hal yang perlu diperhatikan adalah bahwa kedua kata tersebut memiliki makna apabila digunakan dalam kalimat dan tidak bisa berdiri sendiri. Kata Kunci: Tindak Tutur, kata Bi dan Ba, Bahasa Dayak
\end{abstract}

\section{PENDAHULUAN}

Setiap daerah memiliki variasi bahasa dalam bahasa daerahnya. Salah satu contoh variasi bahasa yang berkaitan dengan fungsi kata yang mana penggunaanya memiliki kesamaaan dengan daerah lainnya, misalnya dalam bahasa Jawa yang memiliki variasi kata "ta" dalam kalimat "Jawaban iku bener ta?" dalam bahasa Jawa dialek Malang atau kata "a" dalam bahasa Jawa dialek Surabaya yang digunakan sebagai partikel dalam kalimat interogatif. Adanya variasi ini menimbulkan asumsi bahwa ada kata yang hanya bisa digunakan dalam kalimat tanya atau interogatif dan adapula yang hanya bisa digunakan dalam kalimat imperatif.

Hal ini terjadi hampir di semua bahasa yang tersebar di setiap negara dan penggunaan kata seperti biasanya selalu dikaitkan dengan konteks atau suasana dimana kata itu digunakan. Adanya perbedaan fungsi kata memberikan pengalaman yang berbeda kepada setiap orang yang baru belajar bahasa tertentu dan mungkin menjadi kesulitan tersendiri. Oleh sebab itu, pengetahuan tentang kata harus dipelajari agar penutur dapat menggunakannya dengan benar, karena tiap penutur bahasa hidup dan bergerak dalam sejumlah lingkungan masyarakat yang adat-istiadatnya atau cara pergaulannya berbeda-beda dan mempengaruhi pemakaian kata yang mereka gunakan (Alwi, Dardjowidjojo, Lapoliwa, Moeliono, 2010).

Penempatan kata pada struktur tata bahasa yang benar akan membuat pengguna bahasa 
memahami konteks kalimat, kapan sebuah kata bisa digunakan dan kapan kata itu tidak bisa digunakan. Sebagai contoh, kata think dalam bahasa Inggris biasanya hanya diikuti oleh subjek yang hidup seperti manusia - Tuti thinks that Izzi should buy a new car. Dalam kalimat ini, jelas bahwa subjek yang bisa berpikir hanyalah manusia, sedangkan hewan dan tumbuhan tidak bisa melakukan proses berpikir. Oleh sebab itu, kata think dalam fungsinya hanya akan menempatkan manusia sebagai subjek dan tidak bisa digantikan dengan subjek yang lain. Fenomena seperti ini tentu tidak hanya terjadi dalam bahasa Inggris saja, tetapi juga pada bahasa lainnya. Indonesia sebagai negara yang memiliki lebih dari 17.000 pulau dan 6.000 lebih berpenghuni dengan lebih dari 300 bahasa yang terdapat di sana (Forshee,2006), maka tidak bisa dipungkiri bahwa bahasa-bahasa yang tersebar di Indonesia memiliki keragaman fungsi kata yang membedakannya dengan daerah lainnya.

Sebagai bagian penting dari kalimat, fungsi kata memberikan gambaran akan adanya kepaduan struktur kalimat yang membentuk wacana sehingga mudah dibaca dan dipahami oleh masyarakat umum. Oleh sebab itu, pemahaman akan fungsi kata dalam kalimat sangat penting karena kata adalah sarana penting yang digunakan oleh manusia untuk berkomunikasi. Tidak hanya itu, kata sebagai unsur penting dari bahasa perlu dipelajari oleh penuturnya karena dengan kata problematika kebahasaan akan terpecahkan (Schmitt dan Celce-Murcia, 2002). Pemahaman ini membuktikan bahwa kata tidak bisa dipisahkan dari kehidupan manusia. Manusia menggunakan kata di setiap bidang kehidupan untuk menjelaskan segala sesuatu yang ada disekelilingnya. Oleh sebab itu, kata tidak hanya diperlakukan sebagai wadah makna atau memenuhi peran dalam peristiwa, tetapi juga memiliki hubungan satu sama lain (Yule, 2015) yang berhubungan dengan konteksnya.

Salah satu fenomena yang melibatkan penggunaan kata terdapat pada masyarakat Dayak di desa Riam Durian. Riam Durian merupakan sebuah desa yang terletak di kecamatan Kotawaringin Lama, kabupaten Kotawaringin Barat, Kalimantan Tengah. Menurut Badan Pusat Statistik (BPS) Kotawaringin Barat (2016), Riam Durian memiliki luas wilayah sekitar 22,45 km2 dengan mayoritas penduduk bekerja sebagai petani dan ada pula yang bekerja sebagai buruh di perusahaan swasta. Perkebunan kelapa sawit dan karet merupakan penyumbang terbesar dalam perekonomian masyarakat. Lebih lanjut, suku yang tinggal di Riam Durian berasal dari suku Dayak sebagai suku asli dan mayoritas, sedangkan suku Jawa, Flores, dan juga Batak hanya sebagai suku pendatang dengan jumlah kecil. Selain itu, bahasa yang digunakan oleh sebagian besar masyarakat di desa Riam Durian adalah bahasa Dayak. Adapun bahasa Dayak digunakan sebagai bahasa komunikasi sehari-hari baik oleh orang dewasa maupun anak-anak yang kemudian disusul dengan penggunaan bahasa Indonesia jika bersentuhan dengan masyarakat yang bukan Dayak.

Berdasarkan penulis sebagai penutur asli bahasa Dayak di Riam Durian bahwa sebagian besar kosakata bahasa Dayak mengadopsi kosakata dari bahasa Indonesia yang berasal dari bahasa Melayu misalnya kata 'belum' yang berubah bentuk menjadi 'bolum/ boluman' atau 'gemuk menjadi 'gomuk.'Namun, meskipun mengadopsi kosakata dari bahasa Indonesia, ternyata ada pola-pola tertentu yang yang berbeda dalam membuat kalimat terutama kalimat imperatif dan kalimat interogatif. Misalnya kata ba dan bi , dua kata ini hanya digunakan pada konteks tertentu saja meskipun pada kenyataannya sering digunakan.

Dalam percakapan sehari-hari dua kata ini digunakan berulang-ulang baik oleh anak- 
anak maupun oleh orang dewasa. Sebagai contoh, kata hee bi? --iyakah atau hee ba -iyalah. Berdasarkan dua contoh tersebut bisa dipahami bahwa kedua kata ini tidak mengalami perubahan bentuk dan hanya berfungsi untuk menampilkan unsur yang diiringinya sehingga tergolong dalam klasifikasi kata tugas sebagai bagian dari partikel penegas (Alwi, Dardjowidjojo, Lapoliwa, dan Moeliono, 2010). Selain itu, hal yang perlu diperhatikan adalah kata bi hanya digunakan dalam kalimat interogatif dengan jawaban 'ia' atau 'tidak' dan tidak bisa digunakan dalam kalimat tanya yang membutuhkan alasan seperti 'mengapa' dan 'bagaimana.'

Penggunaaan kata $b a$ dan bi pada dasarnya bersifat universal yang artinya bahwa setiap orang dari semua kalangan, status sosial, umur, tingkat pendidikan, pekerjaan, dan juga gender bisa menggunakan kedua kata ini. Namun ternyata, tidak semua lapisan masyarakat bisa menggunakan kata $b a$ dan $b i$ sesuai dengan konteksnya terlebih pendatang. Padahal, konteks memainkan peranan yang penting untuk memahami fungsi kata dalam kalimat. Kata sebagai unit pembentuk kalimat perlu dikaji makna dan penggunaannya agar kata tersebut tidak ambigu dan masyarakat tidak salah dalam mengartikannya.Ambiguitas dalamkalimatperludihindarikarenamenimbulkaninterpretasiyangsalah.

Lebih lanjut, kata $b a$ dan $b i$ juga memainkan peranan penting dalam menentukan formulasi struktur bahasa Dayak di Riam Durian terutama dalam pembentukan kalimat imperatif dan interogatif. Dua kata ini menjadi unsur penting yang harus ada dan bersifat mutlak keberadaanya sehingga tidak bisa diabaikan. Untuk menentukan formulasi ini, maka perlu dilihat kolokasi-kolokasi yang mengikuti dua kata ini apakah diikuti oleh kata kerja atau kata benda. Sayangnya, sumber tertulis mengenai struktur bahasa Dayak di Riam Durian sejauh penelurusan penulis belum ditemukan. Lebih lanjut, kata ba dan bi juga berhubungan dengan teori tindak tutur yang dikemukan oleh Searle. Hal ini mendorong penulis untuk mengkaji bagaimana sebenarnya keterkaitan antara dua kata ini dengan teori tindak tutur.

Berdasarkan uraian di atas, penulis bermaksud membuat tulisan ini dengan tujuan menjelaskan fungsi penggunaan kata bi dan ba dalam bahasa Dayak di Riam Durian dengan berfokus pada analisis struktur kalimat bi dan ba lalu menghubungkannya dengan teori tindak tutur. Selain itu, penulis juga bermaksud menggambarkan pada jenis kalimat seperti apa kedua kata ini digunakan, apakah kata bi bisa dimasukkan dalam kalimat yang menggunakan ba dan sebaliknya. Penulis juga ingin menunjukkan konteks kalimat seperti apa yang muncul ketika dua kata ini digunakan. Apakah ada partikel yang sama muncul mengikuti dua kata ini atau mereka memiliki partikel yang berbeda. Selain itu, penelitian ini diharapkan mampu menjadi informasi tambahan yang membahas bahasa Dayak di Riam Durian karena penelitian dibidang bahasa Dayak ini masih belum ada. Hasil penelitian ini juga diharapkan mampu menggambarkan kondisi kebahasaan di Riam Durian untuk memperkaya koleksi penelitian serta menjadi referensi bagi peneliti lain untuk membuat kajian yang serupa pada bahasa Dayak dengan menggunakan pendekatan yang berbeda. penelitian ini juga diharapkan mampu memberikan gambaran kepada pendatang mengenai bahasa Dayak sehingga tidak ada kesalahan dalam menggunakan dua kata ini.

\section{KAJIAN PUSTAKA DAN METODOLOGI}

Kelas kata memiliki peranan penting dalammengklasifikasikan kata. Adapun kelas kata dalam bahasa Indonesia adalah kata kerja, kata benda, adjektiva serta kata tugas. Kata kerja memiliki 
makna inheren yang terkandung di dalamnya misalnya lari atau belajar yang mengandung makna inheren perbuatan dan biasanya kata kerja dapat menjadi jawaban untuk pertanyaan apakah yang dilakukan oleh subjek. Berbeda halnya dengan verba, kata benda adalah kata yang mengacu pada manusia, binatang, benda, dan konsep atau pengertian seperti kebangsaan, guru, kambing dan meja(Alwi, Dardjowidjojo, Lapoliwa, dan Moeliono, 2010). Lebih lanjut, adjektiva adalah kata yang memberikan keterangan lebih khusus tentang sesuatu yang dinyatakan oleh nomina dalam kalimat. Keterangan biasanya berkaitan dengan kualitas atau keanggotaan dalam suatu golongan seperti kecil, berat, merah, bunda dan ganda. Selain itu, adjektiva dapat berfungsi sebagai predikat dan adverbial kalimat dan biasanya mengacu pada suatu keadaan.

Terakhir, kata tugas adalah kata yang hanya mempunyai arti gramatikal dan tidak memiliki arti leksikal. Arti suatu kata tugas ditentukan bukan oleh kata itu secara lepas, melainkan kaitannya dengan kata lain dalam frasa atau kalimat. Selain itu, kata tugas hampir tidak dapat menjadi dasar untuk membentuk kata lain seperti mendatangi atau mendatangkan (Alwi, Dardjowidjojo, Lapoliwa, dan Moeliono, 2010). Kata tugas terbagi menjadi lima klasifikasi dalam frasa atau kalimat yakni preposisi, konjungtor, interjeksi, artikula dan partikel penegas. Dalam penelitian ini, peneliti hanya membahas partikel penegas karena kata bi dan ba memenuhi syarat sebagai partikel penegas karena bermakna -kah dan -lah.

Menurut Alwi, Dardjowidjojo, Lapoliwa, dan Moeliono (2010) sifat dari partikel penegas adalah suatu kata yang tidak tertakluk pada perubahan bentuk dan hanya berfungsi menampilkan unsur yang diiringinya. Ada empat macam partikel penegas yaitu -kah, -lah, -tah, dan pun. Tiga yang pertama berupa klitika dan yang keempat tidak. Partikel -kah yang berbentuk klitika dan bersifat manasuka dapat menegaskan kalimat interogatif seperti bonar bi enya datang nihinam? -benarkah dia datang sekarang?. Selain itu, pemakaian -kah menjadikan kalimatnya lebih formal dan sedikit lebih halus serta jika dalam kalimat tidak ada kata tanya tetapi intonasinya adalah intonasi interogatif, maka -kah akan memperjelas kalimat itu sebagai kalimat interogatif seperti tidak dapai ia mengurus soal sekecil itu? menjadi tidak dapatkah ia mengurus soal sekecil itu?. Lebih Lanjut, partikel -lah bisa dipakai dalam kalimat imperatif dan deklaratif. Dalam kalimat imperatif,-lahdipakai untuk menghaluskan nada perintah, sebagai contoh dalam bahasa Dayak hidupi ba kompor nia ne -tolonglah nyalakan kompor itu. Nada perintah dalam kalimat ini diperhalus dengan tambahan partikel -lahpada kata tolong.

Berdasarkan uraian di atas, katabi dan ba dalam kalimat akan dilihat fungsinya berdasarkan sudut pandang sintak. Kalimat yang memakai dua kata ini akan dijabarkan fungsinya berdasarkan aturan yang benar dalam kaidah kalimat secara gramatika atau dengan memperhatikan struktur kalimat seperti subjek, predikat, objek, pelengkap dan adverbia sehingga ketika diterapkan secara wajar, tidak akan mengarah pada struktur yang salah (Yule, 2015). Selain itu, dengan memakai sudut pandang sintak, fungsi kata bi dan ba akan mudah terlihat dalam hal bagaimana pola kalimat ketika dua kata ini muncul apakah berpola kalimat deklaratif, imperatif, atau interogatif.

Jenis kalimat berdasarkan fungsinya terbagi dalam tiga jenis yakni deklaratif, imperatif, dan interogatif (Yule, 1996) sama seperti yang telah disebutkan oleh Wijana. Kalimat deklaratif 
disebut dengan kalimat pernyataan. Selain itu, adapula yang menyebut kalimat ini sebagai kalimat berita (Alwi, Dardjowidjojo, Lapoliwa, dan Moeliono, 2010). Dalam pemakaian bahasa, bentuk kalimat deklaratif umumnya digunakan oleh penutur/penulis untuk membuat pernyataan sehingga isinya merupakan berita bagi pendengar atau pembacanya. Sebagai contoh, jika pada suatu saat kita mengetahui ada kecelakaan lalu lintas dan kemudian kita menyampaikan peristiwa itu kepada orang lain, maka kita dapat menyampaikan atau memberitakan kejadian ini dengan menggunakan bermacam-macam bentuk kalimat deklaratif, misalnya 'Ada kecelakaan mobil tadi pagi di dekat Monas' atau 'Saya lihat ada bus masuk Ciliwung tadi pagi' dan bisa juga 'Tadi pagi anak kecil ditabrak oleh sepeda motor di dekat Monas.' Dari segi bentuknya, kalimat di atas dapat berupa kalimat aktif dan kalimat pasif, namun jika dilihat dari fungsi komunikatifnya, semua kalimat di atas merupakan sebuah kalimat berita. Dengan demikian, kalimat berita dapat berupa bentuk apa saja, asalkan isinya merupakan suatu pemberitaan.

Berbeda halnya dengan Yule (1996), Yule menjelaskan bahwa kalimat deklaratif juga bisa dipakai untuk membuat sebuah permintaan (request) bila digunakan dalam tuturan tidak langsung, misalnya dengan menggunakan kalimat 'I hereby request you that you close the door.' Dengan munculnya kata 'hereby', lalu kemudian diikuti oleh kata 'request', menandakan bahwa penutur secara tidak langsung menyatakan suatu pemberitaan kepada pendengarnya untuk menutup pintu. Penegasan ini ditandai dengan munculnya kata 'request' untuk memperkuat adanya indikasi kalimat berita.

Berkaitan dengan kalimat imperatif, kalimat imperatif selalu berhubungan dengan perintah atau memerintah. Alwi, Dardjowidjojo, Lapoliwa, dan Moeliono (2010) menerangkan bahwa dari segi isi, kalimat imperatif memiliki enam golongan yaitu (1) perintah atau suruhan biasa jika penutur menyuruh lawan tuturnya melakukan sesuatu; (2) perintah halus jika penutur tampaknya tidak memerintah, tetapi menyuruh mencoba atau mempersilakan lawan tutur sudi berbuat sesuatu; (3) permohonan jika penutur demi kepentingannya, meminta lawan tuturnya berbuat sesuatu; (4) ajakan dan harapan jika penutur mengajak atau berharap lawan tutur berbuat sesuatu; (5) larangan atau perintah negatif jika penutur menyuruh agar jangan dilakukan sesuatu; dan (6) pembiaran jika penutur meminta jangan dilarang. Inilah prinsip tentang kalimat imperatif yang disampaikan oleh Alwi dkk. Segala bentuk larangan dan permohonan dikategorikan sebagai bagian dari kalimat imperatif.

Alwi, Dardjowidjojo, Lapoliwa, dan Moeliono (2010) juga menambahkan ciri formal dari kalimat imperatif, yakni: intonasi yang ditandai nada rendah diakhir tuturan, pemakaian partikel penegas, penghalus, dan kata tugas ajakan, harapan, permohonan, larangan. Terlebih, susunan kalimatnya inversi sehingga urutannya menjadi tidak selalu terungkap, predikat-subjek jika diperlukan, dan yang terakhir adalah pelaku tindakan tidak selalu terungkap. Selain itu, kalimat imperatif dapat diwujudkan melaluibeberapa cara, yaitu denganmembentuk kalimat yang terdiri dari predikat verbal dasar atau adjektiva ataupun frasa preposisional saja yang sifatnya taktransitif, kalimat lengkap yang berpredikat taktransitif atau transitif, dan kalimat yang dimarkahi oleh berbagai kata tugas modalitas kalimat. 
Jenis kalimat yang ketiga adalah kalimat interogatif. Menurut Alwi, Dardjowidjojo, Lapoliwa, dan Moeliono (2010) kalimat interogatif atau umumnya disebut dengan kalimat tanya, secara formal ditandai oleh kehadiran kata tanya seperti apa, siapa, berapa, kapan, bagaimana dengan atau tanpa partikel-kah sebagai penegas. Kalimat interogatif diakhiri dengan tanda tanya(?) pada bentuk tertulis dan pada bahasa lisan biasanya ditandai dengan suara naik, terutamajika tidak ada kata tanya atau suara turun. Bentuk kalimat interogatif biasanya digunakan untuk meminta (1) jawaban "ya" atau "tidak", atau (2) informasi mengenai sesuatu atau seseorang. Mereka menambahkan bahwa ternyata kalimat deklaratif juga bisa dibentuk menjadi kalimat interogatif, yakni (1) dengan menambahkan partikel penanya apa, (2) dengan membalikkan susunan kata, (3) dengan menggunakan kata bukan(kah) atau tidak(kah), dan (4) dengan mengubah intonasi menjadi naik ketika dalam komunikasi lisan.

Jenis kalimat yang telah dijelaskan di atas tidak bisa dipisahkan dalam proses komunikasi masyarakat yang disebut tindak tutur. Tindak tutur menggambarkan tindakan yang dilakukan oleh penutur kepada lawan tuturnya seperti meminta, memerintahkan, menanyakan atau menginformasikan atau dengan kata lain tindak tutur adalah perbuatan penutur dengan sebuah tuturan (Yule, 2015). Menurut Yendra (2016), tindak tutur merupakan ujaran yang bersifat fungsional dalam komunikasi. Di mana, tindak tutur merupakan tujuan dari penggunaan kalimat yang dituturkan oleh penutur seperti memuji, meminta maaf, memberi saran dan berbagai fungsi lainnya. Fungsi tersebut tidak dapat ditentukan hanya dari bentuk leksikal dan gramatikalnya, melainkan berdasarkan konteks yang digunakan pada bahasa tersebut. Konteks memberikan gambaran akan suatu tuturan dapat diujarkan dan kapan suatu ujaran tersebut tidak dapat dituturkan karena mungkin mengandung makna yang berkonotasi negatif. Selain itu, aspek secara komprehensif dan situsional dapat mempengaruhi tindak tutur dalam berkomunikasi.

Menurut Wijana (dalam Setiawan, 2014), tindak tutur dibedakan ke dalam tindak tutur langsung dan tidak langsung serta tindak tutur literal dan tidak literal (non-literal). Tindak tutur langsung adalah tindak tutur yang mana fungsi kalimat yang diujarkan sesuai dengan fungsi secara umum dari kalimat tersebut. Kalimat tersebut dapat memiliki kategori sebagai kallimat berita (deklaratif), kalimat tanya (interogatif), dan kalimat perintah (imperatif). Di lain sisi, tindak tutur tidak langsung adalah tindak tutur yang mana kalimat yang diujarkan tidak sesuai dengan fungsi umum dari kalimat tersebut. Sebagai contoh, kalimat interogatif di mana ya sapunya? $\neg-$ konteks kalimat tersebut diucapkan seorang ibu kepada anaknya dengan tujuan tidak untuk mengetahui tempat sapu tersebut, tetapi secara tidak langsung memberikan perintah kepada anaknya untuk menyapu lantai itu. Dalam tindak tutur tidak langsung terdapat perubahan fungsi kalimat secara umum ke dalam kalimat yang disesuaikan dengan situasinya.

Lebih lanjut, tindak tutur literal adalah tidak tuturyang memiliki tujuan sama dan sesuai dengan kata-kata yang tersusun di dalam kalimat tersebut,contohnya lukisan Tanti sangat indah yang mana kalimat tersebut bertujuan untuk memuji lukisan Tanti yang memang indah dan tidak memiliki maksud lain dari kalimat tersebut. Tindak tutur tidak literal (non-literal) adalah suatu tindak tutur yang memiliki tujuan dan maksud yang berbeda dengan kata yang dibentuknya, misalnya nyalakan saja televisinya dan aku sedang belajar. Dalam kalimat tersebut terdapat kontradiksi yang menjelaskan bahwa kalimat tersebut tidak ditujukan agar seseorang menyalakan televisi melainkan mematikan televisi. Dengan 
demikian, tindak tutur literal maupun non literal dapat dipengaruhi situasi dari masyarakat sekitarnya.

Selain itu, dalam proses bertutur seorang penutur secara bergantian memperlihatkan tiga tipe acts yakni lokusi, perlokusi, dan ilokusi (Duranti, 1997). Lokusi atau locutionary actadalahtindak tutur mengatakan sesuatu dan bisa diinterpretasikan berdasarkan konvensi gramatikal serta terkadang mengandung nilai kebenaran misalnya, Unyil dipecat minggu lalu. Perlokusi atau perlocutionary act adalah tindak tutur yang dituturkan oleh seseorang seringkali mempunyai daya pengaruh bagi yang mendengarkan.Lebih lanjut, ilokusi atau illocutionary act merupakan tindak tutur yang berfungsi untuk menyatakan atau menginformasikan sesuatu dan dipergunakan untuk melakukan suatu tindakan. Sebagai contoh, ujian sudah dekat -jika diucapkan oleh seorang guru kepada muridnya maka ilokusinya yaitu murid harus bersiap-siap karena ujian sudah dekat. Tetapi jika diucapkan oleh orang tua maka seorang anak harus berhenti bermain dan harus belajar dengan tekun. Dalam perkembangan selanjutnya, Searle (1976, dalam Duranti, 1997) mengklasifikasikan tindak tutur ilokusi ke dalam lima makro fungsi yaitu komisif, direktif, ekspresif, deklaratif dan refresentatif yang sebelumnya dicetuskan oleh Austin pada tahun 1962.

Menurut Searle (1976, dalam Susanti \& Siregar, 2010; Mey, 2001; Duranti, 1997) (1) Tindak Tutur Komisif merupakan tuturan yang bersifat memberikan suatu komitmen atau janji pada penutur, berfungsi untuk menyenangkan, dan kurang bersifat kompetitif karena tidak mengacu kepada kepentingan penutur tetapi kepada penutur; (2) Tindak Tutur Direktif merupakan tuturan yang digunakan oleh penutur untuk mempengaruhi penutur dantindak tutur ini membutuhkan kesantunan negatif karena bersifat mempengaruhi atau memerintahkan penutur; (3) Tindak Tutur Ekspresifberfungsi untuk mengungkapkan atau mengutarakan sikap psikologis penutur terhadap keadaan yang tersirat, bisa berupa pujian, permintaan maaf, kritikan, pengucapan selamat, dan terima kasih; (4) Tindak Tutur Deklaratif merupakan tindak tutur yang berfungsi untuk menyatakan sesuatu dan mengubah statusnya, seperti pengunduran diri, hukuman, pembaptisan, pernikahan, penobatan, melarang, pemberian maaf, perizinan dan memutuskan, dantindak tutur deklaratifini merupakan suatu tindakankelembagaansehinggatidakmelibatkan faktorkesantunan;dan(5)TindakTuturRepresentatif merupakan tindak tutur yang terikat pada kebenaran proposisi yang diungkapkan, sehingga dapat dibuktikan kebenarannya. Dalam penggunaannya, tindak tutur representatif melibatkan kesantunan positif,kecualimengeluhdanmembualyangmenggunakankesantunannegatif.Kalimatyang berisikan sebuah pernyataan, pengakuan, dan pelaporan merupakan beberapa bentuk tindak tutur deklaratif.

Uraian di atas memberikan gambaran bahwa tindak tutur memiliki peranan penting dalam proses komunikasi suatu bahasa. Hal ini disebabkan tindak tutur seseorang tercermin dari kata yang digunakannya. Selain itu, konsep tindak tutur mempermudah seseorang untuk mengetahui maksud dan niat lawan tuturnya atau tujuan yang ingin dicapai lawan tutur. Karena hal inilah kemudian oleh Sukma, Agustina, dan Ngusman (2012) tindak tutur dikatakansebagai inti dari suatu pembicaraan. Inti dari suatu pembicaraan ini bisa diteliti berdasarkan fungsi kata yang membangun makna dalam kalimat.

Sebagai inti dari suatu pembicaran, tindak tutur seperti ilokusi -komisif, direktif, ekspresif, deklaratif dan refresentatif berkaitan erat dengan jenis kalimat seperti deklaratif, imperatif maupun interogatif. Dikatakan demikian karena jika diperhatikan kalimat deklaratif atau kalimat perintah memenuhi unsur tindak tutur direktif yakni memerintahkan lawan tutur untuk melakukan sesuatu. 
Contoh dalam bahasa Dayak di desa Riam Durian lari mam ba kolai dari rumah hin! -pergilah kamu dari rumah ini!. Masyarakat Dayak di desa Riam Durian pada umumnya mengerti bahwa ini adalah kalimat imperatif karena munculnya kata kerja yang dilengkapi dengan partikel penegas -lah menjadi pergilah. Dalam pada itu, motivasi dibalik tuturan ini adalah penutur bermaksud mengusir lawan tuturnya karena disebabkan suatu hal yang tidak menyenangkan sehingga perbuatan mengusir harus segera dilakukan. Adanya indikasi memerintakan untuk segera pergi dalam kalimat lari mam ba kolai dari rumah hin! memenuhi unsur kalimat imperatif maupun tindak tutur direktif.

Terlepas dari hal-hal di atas, penelitian ini merupakan penelitian kualitatif karena data yang digunakan berupa kata yaitu bi dan ba dalam bahasa Dayak di desa Riam Durian. Penelitian ini dikategorikan sebagai penelitian kualitatifkarenajenis data yang ditemukan dalam penelitianiniadalah berupa kata dalam bahasa Dayak yang dianalisis penggunaanya dalam kalimat. Hal ini sejalan dengan yang dikatakan oleh Creswell (1998) bahwa bentuk data yang tergolong dalam penelitian kualitatif adalah berupa gambar, kata, dan kalimat yang dianalisis secara induktif, berfokus pada pendeskripsian sebuah proses yang ekspresif dan persuasif dalam bahasa. Selain itu, penelitian kualitatifberfokus pada deskripsi dan interpretasi terhadap fenomena sosial dan people's account sebagai data (Hancock, Ockleford, dan Windridge, 2007). Pengertian ini sesuai dengan penelitian penulis yang merupakan sebuah fenomena sosial yang ada di tengah masyarakat Dayak di Riam Durian, yakni tentang fungsi kata yang tidak diketahui masyarakat umum tentang kondisi kebahasaannya. Berdasarkan dua pengertian tersebut maka jelaslah bahwa jenis penelitian ini adalah penelitian kualitatif.

Proses pemerolehan data dilakukan penulis dengan menggunakan metode introspeksi terhadap bahasa Dayak di desa Riam Durian, kecamatan Kotawaringin Lama, kabupaten Kotawaringin Barat, Kalimantan Tengah. Menurut Muhammad (2014) metode introspeksi adalah metode penyediaan data dengan memanfaatkan intuisi kebahasaan peneliti yang meneliti bahasa yang dikuasainya (bahasa ibunya) untuk menyediakan data yang diperlukan bagi analisis sesuai dengan tujuan penelitiannya. Jadi, metode ini menyediakan data dengan kemampuan atau intuisi kebahasaan yang dimiliki oleh penulis karena penulis merupakan penduduk asli Dayak yang bermukim di Riam Durian.

Adapun untuk memvalidasi data, penulis menggunakan teknik simak libat cakap. Menurut Mahsun (2014) teknik simak libat cakap adalah suatu cara yang ditempuh oleh penulis dengan menyadap pembicaraan atau penggunaan bahasa yang juga melibatkan penulis di dalam bentuk komunikasinya. Dalam hal ini, penulis melibatkan diri langsung dalam percakapan sehari-hari dengan empat orang penutur asli sebagai informan. Setelah penulis menyimak penggunaan bahasa berdasarkan masyarakat pengguna bahasa tersebut, penulis selanjutnya melakukan perekaman dan pencatatan data untuk memvalidasi data intuisi kebahasaan peneliti. Penulis kemudian melakukan analisis data dengan menjelaskan fungsi kata bi dan ba apakah termasuk dalam jenis kalimat deklaratif, imperatif, ataukah interogatif dan kemudian menghubungkannya dengan teori tindak tutur yang telah dijelaskan di atas.Langkah-langkah dalam analisis data dilakukan dengan cara di bawah ini.

1.Memperhatikan jenis kalimat yang mengandung kata bi dan ba dalam hasil pencatatan data oleh penulis.

2.Memeriksa penggunaan kata bi dan ba dalam kalimat sesuai dengan jenis kalimat berdasarkan fungsinya yakni imperatif, interogatif, dan deklaratif. 
3.Menentukan penggunaan kata bi dan ba berdasarkan fungsi kalimat.

4.Setelah mendapatkan hasil analisis kata bi dan ba dalam kalimat berdasarkan fungsinya, penulis mencocokan kalimat tersebut dengan ciri-ciri tindak tutur apakah termasuk dalam tindak tutur direktif, komisif, deklaratif, ekspresif, atau representatif.

5.Menyimpulkan hasil temuan penggunaan kata bi dan ba.

\section{PEMBAHASAN}

Yule (1996) dan Wijana (dalam Setiawan, 2014) menjelaskan bahwa ada 3 fungsi kalimat dalam komunikasi yaitu sebagai kalimat imperatif, kalimat deklaratif, dan kalimat interogatif. Kalimat imperatif adalah kalimat yang di dalamnya mengandung perintah. Sebagai contoh, jangan pegang pistol itu! - kalimat ini menunjukkan bahwa penutur meminta lawan tuturnya untuk tidak memegang pistol itu, entah karena lawan tuturnya tidak mengerti cara menggunakan pistol ataupun tidak. Kalimat ini bernada memerintah karena diakhiri dengan tanda seru (!), dan yang paling penting adalah ada suatu keharusan yang dimaksudkan dalam fungsi kalimat jenis ini. Kalimat imperatif ini berfungsi untuk meminta/melarang seseorang untuk melakukan sesuatu.

Disisi lain, kalimat deklaratif adalah kalimat yang di dalamnya berisi pernyataan/berita tentang suatu hal, misalnya Belly memakai baju berwarna biru hari ini. Jika diperhatikan, kalimat ini menyampaikan sebuah informasi kepada pendengar atau pembacanya bahwa Belly memakai baju berwarna biru, bukan merah ataupun hitam. Pernyataan ini berupa sebuah informasi yang disampaikan penutur kepada lawan tuturnya dan bukan Belly sendiri yang mengatakannya. Terakhir, kalimat interogatif adalah kalimat yang di dalamnya berisi pertanyaan. Kalimat ini berfungsi untuk bertanya/meminta informasi kepada orang lain. Kalimat interogatif dapat dibagi menjadi kalimat yang membutuhkan jawaban ya/tidak dan kalimat interogatif yang menuntut jawaban berupa informasi. Contoh dari kalimat ini adalah kenapa engkau menangis? kalimat ini tentu membutuhkan jawaban yang berupa informasi yaitu alasan mengapa lawan tutur yang tidak disebutkan namanya ini menangis. Sama halnya seperti kata ba dan bi dalam bahasa Dayak di daerah Riam Durian, dua kata ini ternyata hanya berfungsi jika digunakan dalam kalimat imperatif dan interogatif serta tidak bisa digunakan dalam kalimat deklaratif. Berdasarkan fungsi dalam kalimat, penggunaan kata bi dan ba bisa dideskripsikan sebagai berikut. Tabel 1

\begin{tabular}{|l|l|l|l|}
\hline & \multicolumn{3}{|c|}{ Fungsi Kata menurut Yule (1996) } \\
\hline & Imperatif & Deklaratif & Interogatif \\
\hline $\mathrm{Bi}$ & & - & $\sqrt{ }$ \\
\hline $\mathrm{Ba}$ & $\sqrt{ }$ & & - \\
\hline
\end{tabular}

a) Penggunaan Kata $\mathrm{Bi}$

a) Penggunaan kata $b i$

Jika dilihat pada tabel 1 di atas, terlihat bahwa fungsi kata $b i$ dalam kalimat yang diucapkan oleh masyarakat Dayak di desa Riam Durian adalah sebagai unsur pemenuhan untuk membuat kalimat interogatif yakni yang berfungsi sebagai partikel -kah (Dardjowidjojo, Lapoliwa, dan Moeliono, 2010) atau apakah jika terdapat patikel tambahan seperti tai. Kata bi hanya 
digunakan dalam kalimat tanya saja dan tidak bisa digunakan dalam kalimat imperatif maupun kalimat deklaratif. Jika digunakan dalam kalimat imperatif maka makna kalimat terdengar aneh. Sebagai contoh penggunaan kata $b i$, perhatikan beberapa contoh kalimat di bawah ini.

\section{Tuti, kolai tai jadi babasuh pingganam bi?}

Tuti, kamu sudah mencuci piring apakah?

Tuti, apakah kamu sudah mencuci piring?

Dalam kalimat di atas, terlihat bahwa kata bi bermakna apakah dan bukan -kah karena terdapat partikel tambahan tai. Jika dilihat dari letaknya ternyata kata ini berada diakhir kalimat. Pada umumnya dalam bahasa Indonesia kata tanya seringkali berada di awal kalimat atau setelah subjek seperti pada hasil terjemahan di atas. Ada pola terbalik antara bahasa Dayak dan bahasa Indonesia di sini. Perbedaan ini tentu menjadi bagian tersendiri yang harus dipahami oleh setiap pemakai bahasa. Selain itu, kata bi tidak bisa diletakkan di depan kalimat menjadi Tuti, bikolai tai jadi bebasuh pingganam?. Jika diterjemahkan dalam bahasa Indonesia maka kalimat ini tidak akan bermakna dan tentu tidak akan di pahami oleh orang Dayak sendiri jika diujarkan. Catatan lain yang juga bisa diamati adalah kehadiran partikel tai yang diletakkan setelah kata kolai. Biasanya, untuk membuat kalimat dengan menggunakan bi harus disertai dengan partikel ini, contoh kolai tai.... bi? (apakah kamu...?), enya tai....bi? (apakah dia-bisa perempuan ataupun laki-laki...?), sidak tai.....bi? (apakah mereka...?), atau kenohonan bi sida tai? (sudahkah mereka ada disana atau apakah mereka sudah disana?). Adapun struktur yang bisa digunakan untuk membuat kalimat yaitu:

-Subjek + tai +kata kerja + bi + ? atau dengan menggunakana kata kenohonam

-Kenohonam + bi + Subjek + tai + ? (mengisyaratkan jawaban pendek, iya atau tidak)

Jika diperhatikan struktur kalimat interogatif di atas, ternyata pada umumnya partikel tai berada di depan subjek dan jika menggunakan kata tanya kenohonan berada di akhir kalimat. Demikian pula dengan partikel bi yang jika digunakan pada kalimat tanya bersubjek tunggal maupun jamak diletakkan di belakang, namun jika digunakan dengan menggunakan kata tanya kenohonam selalu berada di posisi kedua. Secara umum, inilah struktur jika ingin membuat kalimat dalam bahasa Dayak di Riam Durian.

\section{Enya tai nak ke rumah onggotnyaambi?}

Dia ingin pergi kerumah kakeknyaapakah?

Apakah dia ingin pergi kerumah kakeknya?

Sama seperti kalimat nomor 1, arti dari kata bi dalam kalimat di atas adalah "apakah." Namun, ada hal yang menarik disini, adanya partikel-am setelah kata benda onggot atau kakek. Fungsi partikel - am disini adalah sebagai penegasan bahwa enya (merujuk pada dia, bisa laki-laki atau perempuan) benar-benar akan pergi ke tempat kakeknya hanya saja belum tahu kapan waktunya sebentar atau lama. Hal lain yang perlu diketahui ialah jika diterjemahkan dalam bahasa Indonesia letak bi bisa di awal kalimat. Namun, jika kata bi digunakan di awal kalimat dalam bahasa Dayak maka makna kalimat tidak bisa berterima sama sekali dan hal ini bahkan tidak pernah terjadi dalam komunikasi sehari-hari.

\section{Penutur 1: Bebe Sohai datang dari pagi ma.}

\section{Bibi Sohai sudah datang sejak tadi pagi}

Kalimat ini diucapkan dengan nada falling intonation diakhir kalimat.

Penutur 2: Hee bi? 


\section{Benar-kah}

Benarkah

Pada contoh ketiga ini fungsi bi juga digunakan sebagai pertanyaan umpan balik yaitu apakah memang benar Bibi Sohai sudah datang. Dalam hal ini jawaban yang dibutuhkan hanya iya atau tidak saja meskipun kadang-kadang banyak di antara masyarakat menambahkan alasan misalnya dengan menambahkan dengan siapa bibi Sohai datang atau dengan menambahkan keterangan waktu. Hal lain yang perlu juga diketahui bahwa ketika kata hee yang artinya adalah 'iya' atau 'benar' digabungkan dengan kata bi maka dua kata ini melebur sehingga membentuk kata benarkah, dan bisa dipastikan bahwa bi adalah akhiran -kah yang merupakan salah satu unsur yang harus ada dalam kalimat interogatif (Alwi, Dardjowidjojo, Lapoliwa, dan Moeliono, 2010).Selain itu, kalimat bebe Sohai tai datangam juga bisa dijadikan kalimat tanya menjadi bebe Sohai tay datangam bi? hanya dengan menambahkan kata bi setelah kata 'datang.'

\section{Bonar bi umak ke humaam?}

Benar -kah Ibu sudah pergi ke ladang?

Benarkah Ibu sudah pergi ke ladang?

Pada contoh kalimat di atas, terlihat bahwa fungsi bi berubah menjadi akhiran -kah. Menurut penulishaliniterjadikarenakatabidiikutiolehadjektif'benar.'Biasanya,jikakatainidiikutiolehadjektif maka ia akan berubah fungsi menjadi akhiran -kah. Contoh lain adalah uyuh bi menggali sumur tai? yang artinya “sulitkah menggali/membuat sumur?". Sama seperti contoh di atas, fungsi kata $b i$ berubah menjadi akhiran -kah karena peranan kata bi tidak memiliki makna jika berdiri sendiri sehingga ia melebur menjadi akhiran dan digabungkan dengan adjektif sulit. Kata sulit mampu berdiri sendiri dan memiliki makna, sedangkan kata bi tidak. Itulah alasan mengapa kata bi melebur dalam bentuk -kah.

\section{Enyatai mboi ke rumah ulak, hee bi?}

Dia tidak pergi ke rumah paman, benar -kah?

Dia tidak pergi ke rumah paman, benarkah?

Pada contoh kalimat di atas, partikel bi berfungsi sebagai akhiran-kah sebagai bentuk penegasan (Alwi, Dardjowidjojo, Lapoliwa, dan Moeliono, 2010). Perlu diperhatikan pada kalimat di atas bahwa si penutur sebelumnya sudah mendengar informasi terlebih dahulu tentang si enya (perempuan atau laki-laki, tergantung konteks kalimat) yang pergi ke rumah pamannya, hanya saja yang menjadi dasar diucapkannya kalimat ini lebih kepada rasa penasaran si penutur apakah subjek kalimat tersebut benarbenar pergi ataukah tidak sama sekali sehingga jawaban yang dibutuhkan hanya 'iya' atau 'tidak' saja. b) Penggunaan Kata $B a$

Jika dilihat pada Tabel 1 di atas, penggunaan kata $b a$ hanya berfungsi dalam kalimat imperatif (Yule, 1996) dan hampir tidak pernah ditemukan dalam kalimat deklaratif. Ini berarti bahwa $b a$ hanya digunakan dalam kalimat yang mengandung perintah untuk melakukan suatu perbuatan atau aksi demi memenuhi keinginan penutur (Duranti, 1997; Mey, 2001). Kata ba di sebagian masyarakat Riam Durian dipakai untuk sedikit menghaluskan nada perintah ketika berbicara yang bisa berarti dua hal yaitu berfungsi sebagai akhiran -lah (Alwi, Dardjowidjojo, Lapoliwa, dan Moeliono, 2010) dan juga bisa berfungsi tolonglah jika terdapat partikel tambahan seperti ne atau hin. Namun, hal yang harus diperhatikan di sini adalah lawan tutur juga bisa membalikkan 
keadaannya, maksudnya adalah membalikkan perintah si penutur kepada dirinya. Hal ini biasanya sering terjadi ketika kata ba ini digunakan. Perhatikan beberapa contoh kalimat di bawah ini.

1. Penutur 1: Ambikkan ba lading nia ne!

Ambilkan tolonglah pisau itu

Tolonglah ambilkan pisau yang itu!

Penutur 2: Kolai niaam ba!

Kamu saja -lah

Kamu sajalah.

Berdasarkan contoh kalimat di atas, penutur menginginkan agar lawan tuturnya mengambilkan pisau, namun lawan tutur tidak bisa memenuhi permintaan si penutur. Dalam hal ini, ba tidak hanya berfungsi memberikan perintah dari si penutur ke lawan tutur tetapi juga memberikan kesempatan pada lawan tutur untuk mengubah pola perintah agar dilakukan sendiri oleh si penutur. Oleh sebab itu, $b a$ memberikan muatan yang sama baik kepada si penutur maupun kepada lawan tutur. Dengan demikian, tidak ada kewajiban yang harus dilakukan oleh lawan tutur untuk memenuhi permintaan si penutur. Lawan tutur berhak memilih untuk mengiyakan ataupun menolak permintaan si penutur. Hal menarik lainnya yaitu lawan tutur juga menggunakan kata $b a$ dalam merespon permintaan si penutur. Dalam hal ini, sejak kalimat si penutur menggunakan kata kerja 'ambil,' maka kata $b a$ sebagai bentuk respon dari lawan tutur mengacu pada kata 'ambil' bukan 'tolong' lagi. Jadi sebagai kesimpulannya, makna kata $b a$ jika dalam bentuk respon akan mengikuti verba yang diujarkan oleh si penutur.

2. Gantungkan ba bajuku hin!.

Gantungkan tolonglah bajuku.

Tolonglah gantungkan bajuku

Konteks kalimat di atas yakni seorang penutur meminta lawan tuturnya untuk menggantungkan baju dengan menggunakan kata $b a$. Dalam kalimat ini, kata $b a$ mengandung arti tolonglah bukan-lah karena diiringin oleh partikel tambahan yakni hin — gantungkan bajuku menjadi tolonglah gantungkan bajuku. Kalimat tolonglah gantungkan bajuku menandakan bahwa penutur menyuruh dengan sedikit lebih halus kepada lawan tuturnya dengan maksud agar lawan tuturnya membantu sehingga keberhasilan proses menggantung baju lebih besar daripada menggunakan kalimat gantungkan bajuku tanpa kata tolong. Selain itu, dalam membuat kalimat menggunakan $b a$, biasanya yang paling sering dilakukan adalah dengan menambahkan kata kerja dan akhiran -kan sehingga struktur kalimatnya menjadi verba + (-kan) + ba + nomina, dan bisa ditambahkan partikel hin atau ne diakhir kalimat.

3. Penutur 1: Ocak'am kocakkan selawarku hin.

Tolong -lah cucikan celana saya

Tolonglah cucikan celanaku

Penutur 2: Hee ba.

$$
\text { Baik-lah }
$$

Baiklah

Pola kalimat pada penutur 1 sebenarnya mengikuti pola kalimat pada contoh 2 hanya perbedaannya yaitu munculnya partikel -am. Walaupun begitu, partikel ini tidak memberikan perubahan makna pada kalimat, fungsinya hanya menekankan bahwa penutur 1 ingin agar lawan 
tuturnya memcucikan celana mungkin karena penutur 1 sangat lelah bekerja sehingga ia tidak mampu lagi melakukan perbuatan mencuci itu sendiri. jika dalah kasus $b i$, ia berubah fungsi sebagai $\neg$ kah untuk membentuk kalimat tanya, maka dalam kasus $b a$ ini, ia berfungsi sebagai lah. Ini berarti bahwa kata $b a$ berfungsi untuk menekankan bahwa lawan tutur tanpa/tidak keberatan akan mencucikan celana milik penutur hanya jika lawan tutur mengiyakan permintaan si penutur.

\section{Penutur 1: Pogian ke rumah mentuhan Dedi ambikan bajuku.}

Pergi ke rumah mertua Dedi ambilkan baju saya

(Ambilkan bajuku di rumah mertua Dedi)

Penutur 2: Kolai jak ba yang ke rumah mentuha Dedi ne.

Kamu saja -lah yang ke rumah mertua Dedi.

Kamu sajalah yang pergi ke rumah mertua Dedi)

Pada contoh kalimat di atas, penutur yang tidak disebutkan namanya ini meminta agar Dedi saja yang pergi ke tempat mertuanya. Kata jak yang menemi kata $b a$ merupakan sebuah permohonan untuk menolak permintaan penutur terhadap lawan tutur jika dituturkan dengan intonasi yang halus. Ini artinya bahwa penutur 1 ingin agar lawan tutur yang tidak disebutkan namanya ini pergi ke rumah mertua Dedi yang mungkin saja Dedi ini adalah teman akrab penutur 2 atau bahkan sepupu. Namun, jika diujarkan dengan nada suara yang tinggi, maka artinya adalah penutur 2 sedang marah atau sedang tidak ingin diganggu.

Pada contoh kalimat ini perlu juga diperhatikan bahwa ada dua situasi yang ditampilkan di sini. Pertama, penutur adalah orang yang diminta untuk ke rumah mertua Dedi. Maksudnya adalah, orang yang meminta penutur adalah teman sebaya yang bisa diidentifikasi dari kata kolai dan/orang yang memiliki umur tidak jauh berbeda dari penutur. Dalam hal ini, teman peutur memberikan perintah untuk pergi tapi, penutur memberikan respon dengan kalimat bernada imperatif jugadengan mengatakan 'kamu saja yang pergi ke rumah mertua dedi.' Kedua, ada pihak ketiga yang meminta penutur pergi ke rumah mertua Dedi. Ini bisa saja pihak ketiga adalah ibu atau ayahnya penutur. Namun, yang perlu diperhatikan adalah respon penutur bukan ditujukan untuk ayah ataupun ibunya melainkan untuk adiknya atau sepupu yang seumuran dengan dia. Hal ini dikarenakan kata kolai tidak sopan bila digunakan atau ditujukan kepada orang yang lebih tua. Oleh sebab itu, terbentuk dua kalimat imperatif yang bermakna sama-pertama, dari ibu atau ayah penutur yang memintanya pergi ke rumah mertua Dedi; kedua, penutur memproduksi ujaran yang sama yang ditujukan untuk adiknya atau sepupunya yang berumur sama karena mungkin penutur sedang melakukan hal lain sehingga ia tidak bisa melaksanakan perintah ibu atau ayahnya.

\section{Penutur 1: Ocak hantarkanba lauk hin ke rumah busu Juntin.}

Hantarkan tolonglah makanan ini ke rumah busu Juntin

Tolonglah antarkan makanan ini ke rumah Paman Juntin

Berdasarkan contoh di atas, kata $b a$ diterjemahkan menjadi tolonglah karena adanya partikel tambahan hin dalam kalimat. Partikel ini berfungsi untuk menekankan bahwa si penutur menginginkan sekali lawan tuturnya melakukan apa yang diperintahkannya yakni mengantarkan baju ke rumah Paman Juntin. Agar keinginan ini terkabul, maka penutur menambahkan kata ocak sebelum kata $b a$ untuk menandakan bahwa ada tekanan meminta 
dengan lebih agar perbuatan ini dilakukan oleh lawan tuturnya. Sedangkan, jika hanya bermakna tolong maka, makna hanya sekedar meminta bantuan tanpa adanya tendensi yang berlebihan dari penutur terhadap lawan tuturnya. Dilakukannya atau tidak perbuatan menghantar baju ke rumah Paman Juntin tidak terlalu berdampak pada pemenuhan keinginan si penutur.

Dengan adanya contoh kalimat di atas, penggunaan kata $b i$ dan $b a$ di desa Riam Durian memang sangat penting untuk membentuk kalimat imperatif dan interogatif. Dua kalimat ini baik imperatif maupun interogatif merupakan kalimat yang sering digunakan dalam percakapan sehari-hari terutama bagi masyarakat di desa Riam Durian. Kehadiran dua kata ini menjadi bukti bahwa pembentukan kalimat setiap bahasa memiliki pola yang berbeda-beda sehingga dibutuhkan pembelajaran untuk memahami fenomena seperti ini. Oleh sebab itu, pembelajaran kata berdasarkan konteks atau situasi merupakan hal yang sangat krusial dalam mempelajari bahasa.

Duranti (1997) menyatakan bahwa seorang pengguna bahasa harus diinformasikan bahwa ada konteks-konteks atau situasi dimana kata tertentu hanya diucapkan dalam konteks tertentu pula. Hal ini menurut Duranti bertujuan agar pengguna bahasa menempatkan kata tertentu ini berdasarkan setting atau konteks berserta fungsinya dengan tepat sesuai dengan native culture dimana kata itu berasal. Hal ini tercermin dalam penggunaan kata $b i$ dan $b a$ dalam bahasa Dayak di desa Riam Durian. Dua kata ini ternyata hanya berfungsi jika digunakan dalam kalimat imperatif dan interogatif. Jika seorang penutur ingin membuat kalimat yang bernada memerintah, maka kata yang harus digunakannya adalah $b a$. Adanya kata $b a$ yang muncul dalam kalimat akan langsung dimengerti oleh lawan tutur tentang apa yang diinginkan oleh yang membuat tuturan. Dan, hal penting yang harus digarisbawah adalah bahwa lawan tutur mengerti karena adanya perintah hanya dengan kehadiran sebuah kata yakni $b a$. Oleh sebab itu, kehadiran kata $b a$ dalam bahasa Dayak di desa Riam Durian memiliki makna yang sangat penting untuk menandai kalimat perintah. Tanpa kehadiran kata $b a$, maka masyarakat di tempat ini tidak akan mampu membuat kalimat perintah.

Selain itu, kehadiran kata bi dalam bahasa Dayak di desa Riam Durian tak kalah pentingnya seperti fungsi kata $b a$. Bagi masyarakat Riam Durian, akan sulit sekali membuat kalimat tanya atau kalimat interogatif tanpa adanya bantuan dari kata $b i$. Kalimat interogatif hanya bisa dibuat apabila terdapat kata $b i$ di dalamnya. Ketika kata ini tidak digunakan dalam kalimat interogatif, maka makna bertanya juga tidak akan terlihat. Hal inilah yang kemudian menjadi esensi dasar kata $b i$ dalam masyarakat Riam Durian bahwa kata bi memang tidak bisa dilepaskan dari unsur kebahasaan masyarakat ini melihat fungsinya yang bersifat esensial. Oleh sebab itu, pemahaman kata ini penting untuk dimengerti terutama bagi orang-orang yang belajar bahasa Dayak di Riam Durian.

Dalam pada itu, jika dihubungkan dengan teori tindak tutur, maka kata $b i$ cenderung merefleksikan fungsi direktif sebagai salah satu bagian dari teori tindak tutur yakni meminta informasi (Mey, 2001; Duranti, 1997). Sebagai contoh "Enya tai nak ke rumah onggotnyaam $b i$ ? - apakah dia ingin pergi kerumah kakeknya?(Contoh dari penggunaan kata bi, hal. 5), kalimat ini merupakan sebuah permintaan akan informasi dimana penutur menginginkan jawaban apakah si enya (merujuk pada orang ketiga tungga, bisa laki-laki maupun perempuan) pergi ke rumah kakeknya. Dalam hal ini, salah satu syarat dari pemenuhan teori tindak tutur direktif adalah request atau ask dimana penutur meminta lawan tuturnya melakukan sesuatu (Mey, 2001). Jelas terlihat 
bahwa kalimat "Enya nak ke rumah onggotnyaam bi?"memenuhi unsur yang telah disebutkan sebelumnya dimana sebuah informasi sedang ditanyakan oleh penutur dengan harapan mendapatkan jawaban dari lawan tuturnya. Respon dari lawan tutur tidak menjadi landasan dalam menentukan apakah kalimat ini sudah memenuhi unsur direktif, namun yang paling mendasar adalah adanya sebuah permintaan (request) yang berupa pertanyaan akan informasi yang disampaikan oleh penutur.

Contoh lain, "Icuk bi membawak motor tai?" - Apakah Icuk yang membawa sepeda motor? - juga dikatakan memenuhi fungsi direktif karena penutur menginginkan informasi kepala lawan tuturnya tentang apakah benar Icuk yang membawa kendaraan. Atas unsur yang ditemukan pada kata $b i$ inilah, maka kata bi memenuhi syarat untuk dikatakan sebagai bagian dari tindak tutur direktif yakni request atau ask. Namun, hal yang perlu diperhatikan adalah kata bi hanya berfungsi jika digunakan dalam kalimat dan tidak berdiri sendiri. Jika kata ini hanya berdiri sendiri, maka ia tidak bisa dikatakan memenuhi unsur tindak tutur direktif. Contoh lain juga terdapat pada kata $b a$ dalam bahasa Dayak yang tersebar di desa Riam Durian. Melihat dari fungsi kata $b a$, maka penulis berasumsi bahwa kata $b a$ memenuhi unsur sebagai bagian dari tindak tutur komisif. Menurut Searle dan Vanderveken (1985, dalam Duranti 1997) salah satu unsur yang bisa diamati dari tindak tutur komisif adalah lawan bisa accept (menerima) atau refuse (menolak) sebuah permintaan. Contoh:

Penutur 1: ocakam kocakkan selawarku hin. (tolong cucikan celanaku)

Penutur 2: Hee ba.

Baik -lah

Baiklah

Dalam kalimat ini dijelaskan bahwa penutur 1 berusaha meminta bantuan kepada penutur 2 sebagai lawan tuturnya untuk mencucikan celana. Namun, poin penting yang perlu diperhatikan adalah respon dari lawan tutur karena mengandung unsur tindak tutur direktif. Hal ini dikarenakan yang mengiyakan atau menolak permintaan adalah lawan tutur bukan penutur 1. Oleh sebab itu lawan tutur dalam kalimat di atas berperan lebih besar daripada penutur. Jawaban yang diberikan oleh lawan tutur baik itu mengiyakan ataupun menolak sudah memenuhi unsur tindak tutur direktif sebagaimana yang dikatakan oleh Searle dan Vanderveken (1985, dalam Duranti 1997). Karena dalam hal ini, menolak ataupun menerima permintaan merupakan ciri dari tindak tutur komisif. Dalam contoh di atas, terlihat bahwa lawan tutur meluluskan permintaan si penutur untuk menerima dan mengiyakan keinginan si penutur yakni memcuci celana. Contoh lain dari adanya tindak tutur komisif misalnya pada kalimat:

Penutur 1: Ambikkan ba duit di rumah ongah Hajat ne.

Ambilkan tolonglah uang di rumah Paman Hajat.

Tolonglah ambilkan uang di rumah Paman Hajat.

Penutur 2: Kolai jak bameambiknya ne.

Kamu sajalah yang mengambil uang.

Berbeda halnya dengan contoh yang baru saja dijelaskan penulis. Dalam kalimat ini, ternyata lawan tutur lebih memilih untuk tidak menerima permintaan dari penutur 1 dengan mengatakan kolai jak ba meambikknya ne. Meskipun tidak memenuhi permintaan si penutur, jawaban yang diberikan oleh lawan tutur si penutur tetap dikategorikan sebagai 
tindak tutur komisif karena salah satu cirinya yakni bisa menolak permintaan penutur. Dengan adanya kecenderungan pada kata $b a$ yang mengarah pada aspek 'tolak,' maka penulis berasumsi bahwa kata ini memenuhi syarat untuk menjadi bagian dalam tindak tutur komisif.

Jika dilihat dengan adanya ilustrasi berdasarkan data di atas, konteks dan fungsi kata memang menjadi bagian yang harus diperhatikan dalam mempelajari bahasa tertentu. Hal ini dikarenakan konteks dan fungsi kata akan mengantarkan pengguna bahasa pada pemahaman yang cukup untuk menggunakan kata karena tidak semua kata bisa ditempatkan pada semua jenis kalimat. Terkadang, beberapa kata hanya muncul dalam konteks tertentu terlebih dalam bahasa Dayak seperti yang telah dijelaskan di atas. Adanya perbedaan konteks dan fungsi kata semakin menandakan keberagaman bahasa yang secara umum oleh Duranti dikaji dalam ilmu linguistik antropologi. Duranti (1997) mendefinisikan linguistik antropologi sebagai ilmu yang mempelajari bahasa bahasa sebagai sumber budaya dan tuturan sebagai prakter kebudayaan. Kata $b i$ dan $b a$ dalam bahasa Dayak di Riam Durian juga merupakan tuturan yang digunakan dalam dalam percakapan sehari-hari. Oleh sebab itu, dua kata ini merupakan praktek kebudayaan yang dimiliki oleh masyarakat Riam durian yang mungkin saja tidak dijumpai dalam bahasa yang lain. Inilah yang kemudian disebut dengan keunikan bahasa yakni membedakannya dengan bahasa lainya sehingga kata bi dan ba membawa indentitas masyarakat Riam Durian. Dalam pada itu, dua kata ini juga memiliki konteksnya tersendiri jika digunakan dalam kalimatsehingga masyarakat tidak bisa menggunakan dua kata ini sembarangan.

\section{SIMPULAN}

Secara garis besar, fungsi kata $b i$ dan $b a$ dalam bahasa Dayak di desa Riam Durian hanya digunakan dalam kalimat interogatif dan imperatif. Tidak satupun dari mereka yang digunakan dalam kalimat imperatif. Kata $b i$ mengandung arti apakah jika diterjemahkan dalam bahasa Indonesia sehingga fungsi kata ini hanya terdapat dalam kalimat interogatif. Namun, ketika kata ini diikuti oleh kata hee maka, ia berubah fungsi menjadi akhiran $\neg-$ kah untuk membentuk kalimat tanya. Biasanya, bentuk jawaban yang mengiringi kata ini ialah 'ya' atau 'tidak' saja. Adapun struktur untuk membentuk kalimat dengan katabi yaitu subjek + tai + kata $\boldsymbol{k e r j a}+\boldsymbol{b i}+$ ? atau dengan menggunakan kata kenohonam sehingga menjadi - kenohonam $+\boldsymbol{b i}+\boldsymbol{S} \boldsymbol{u b j e k}+\boldsymbol{t a} \boldsymbol{i}+?$ ? Adapun partikel yang mengikuti kata bi adalah $\neg-a m$ dan tai. Dalam pada itu, melihat fungsi kata $b i$ yang hanya digunakan dalam kalimat interogatif maka, jika dikaitkan dengan teori tindak tutur ia memenuhi syarat sebagai bagian dari tindak tutur direktif yakni meminta lawan tutur untuk melakukan sesuatu misalnya meminta sebuah informasi. Hal ini terlihat dalam beberapa contoh yang telah dijelaskan di atas karena mengandung unsur ini.

Berbeda halnya dengan kata $b i$, kata $b a$ mengandung arti tolonglah jika diterjemahkan dalam bahasa Indonesia yang diikuti oleh patikel ne. Ketika kata ini diikuti oleh kata hee maka, ia berubah fungsi menjadi akhiran-lah untuk mengiyakan permintaan si penutur.Adapun partikel yang mengikuti kata $b a$ ialah hin dan ne dan biasanya partikel hin ditempatkan pada akhir kalimat walaupun tidak berjejer langsung dengan kata $b a$ untuk memperhalus bentuk perintah sedangkan, partikel $n e$ bisa ditempatkan sebelum kata $b a$ dan diakhir kalimat. Selain itu, penulis menemukan bahwa kata $b a$ dalam kalimat juga memenuhi syarat sebagai bagian dari tindak tutur komisif karena adanya unsur 'tolak' 
dan 'terima' dalam penggunaanya terutama untuk respon lawan tutur terhadap permintaan penutur.

Namun, hal yang perlu digarisbawahi adalah penggunaan dua kata ini baik bi maupun $b a$ tidak bisa berdiri sendiri. Mereka harus digunakan dalam kalimat agar memiliki makna, jika tidak digunakan dalam kalimat maka dua kata ini sama sekali tidak bermakna baik itu 'apakah' ataupun tolong. Selain itu, dalam penggunaannya, dua kata ini tidak bisa ditempatkan di depan kalimat, hanya bisa ditempatkan di tengah kalimat atau diakhir kalimat saja. Jika berada di depan kalimat maka, makna kalimat tidak akan dapat diterjemahkan dalam bahasa Indonesia karena dianggap tidak sesuai dengan tata bahasa yang berlaku di masyarakat Dayak yang berada di Riam Durian. Oleh sebab itu, pemakaian dua kata ini harus dipelajari agar tidak terjadi kesalahan dalam penggunaannya terutama bagi mereka yang mempeajari bahasa di Riam Durian. Dengan demikian, konteks dan fungsi kata sangatlah penting dalam menentukan fungsi kata karena mengantarkan pengguna bahasa pada pemahaman yang mendalam akan penggunaan kata.

Selain itu, dengan adanya hasil penelitian tentang konteks penggunaan ba dan bi dalam bahasa Dayak di desa Riam Durian mampu memberikan pengetahuan baru dalam struktur kalimat bahasa Dayak yang umumnya belum diketahui masyarakat luas. Selain itu, hasil penelitian ini menjadi bukti bahwa ternyata bahasa Dayak memiliki keunikan tersendiri sehingga perlu adanya peneliti-peneliti selanjutnya untuk menggali lebih dalam varian bahasa Dayak lainnya yang pada akhirnya bermanfaat dalam proses pembelajaran di masa mendatang.

\section{PUSTAKA ACUAN}

Alwi, H., Dardjowidjojo, S., Lapoliwa, H., Moeliono, Anton M. (2010). Tata Bahasa Baku Bahasa Indonesia (Edisi Ketiga). Jakarta: Balai Pustaka.

Badan Pusat Statistik (BPS) Kotawaringin Barat. (2016). Statistik Daerah Kecamatan

Kotawaringin Lama. Pangkalan Bun: Badan Pusat Statistik (BPS) Kotawaringin Barat.

Creswell, J. W. (1998). Qualitative Inquiry and Research design choosing among five traditions. USA:Sage Publications.

Duranti, A. (1997). Linguistic Anthropology. UK: Cambridge University Press.

Forshee, J. (2006). Culture and Customs of Indonesia. USA: Greenwood Press.

Hancock, B., Ockleford, E ., and Windridge, K. (2007). An Introduction to Qualitative Research. The NIHR RDS EM / YH.

Mahsun. (2014). Metode Penelitian Bahasa; Tahapan Strategi, Metode, dan Tekniknya (Edisi Revisi). Jakarta: Rajawali Pers.

Mey, Jacob L. (2001). Pragmatics: An Introduction (Second Edition). UK: Blackwell Publishing. Muhammad. (2014). Metode Penelitian Bahasa. Yogyakarta: AR-RUZZ MEDIA.

Schmitt, N., Celce-Murcia, M. (2002). An overview of applied linguistics. Diakses dari laman http://faculty.mu.edu.sa/public/uploads/1392140000.1655Applied\%20L\%20-\%20Lecture\%20 $1 \% 20 . p d f$.

Setiawan, Edo. (2014). Interseksi Jenis-Jenis Tindak Tutur pada Komik Kambing Jnatan Karya Raditya Dika. Skriptorium Jurnal No. 2, Vol. 2. Surabaya: Universitas Airlangga.

Sukma, F. R., Agustina, \& Ngusman. (2012). Kesantunan Berbahasa Minangkabau dalam Tindak 
Tutur Menyuruh di Kenagarian Tambang Kecamatan IV Jurai Kabupaten Pesisir Selatan. Jurnal Pendidikan dan Sastra Indonesia Vol 1, No. 1, 515-599.

Susanti, R., \& Siregar, M. (2010). Tindak Tutur Memuji Bahasa Jepang di Kalangan Wanita Jepang.Jurnal Lingua Cultura Vol. 4 No.1, 78-89.

Yendra. (2016). Mengenal Ilmu Bahasa (Linguistik). Yogyakarta: Deepublish.

Yule, G. (1996). Pragmatics. UK: Oxford University Press.

Yule. G. (2015). Kajian Bahasa (Edisi Kelima). Yogyakarta: Pustaka Belajar. 